\title{
Space of visual and circadian parameters of RGBW lighting systems
}

\author{
D. Kalustova \\ V. Lashkaryov Institute of Semiconductor Physics \\ NAS of Ukraine, \\ Ukraine \\ Email: dariakalustova@gmail.com
}

\author{
A. Rybalochka, \\ V. Lashkaryov Institute of Semiconductor Physics \\ NAS of Ukraine, \\ Ukraine \\ Email: andriy.rybalochka@gmail.com
}

\author{
V. Kornaga \\ V. Lashkaryov Institute of Semiconductor Physics \\ NAS of Ukraine, \\ Ukraine \\ Email: vasyak1284@gmail.com
}

\author{
S. Valyukh \\ Linköping University, \\ Sweden \\ Email: sergiy.valyukh@liu.se
}

\begin{abstract}
Due to the proven effect of light on human circadian rhythms, nowadays researchers and developers of lighting systems (LS) concentrate on the non-visual parameters of light and methods of ensuring a safe comfortable light environment. This requires optimisation of spectral power distribution (SPD). In this view the most promising and functional are RGBW systems due to their ability to change dynamically SPD and, hence, light parameters. In this work we explore two RGBW (red-greenblue-white) systems with different white LEDs (warm white and neutral white) and the space of visual and non-visual parameters that they can ensure. Visual parameters are studied in terms of colour rendering index, colour fidelity index and visual corneal illuminance while non-visual parameters are studied in terms of circadian light, circadian stimulus and circadian action factor. These parameters are calculated for different contribution of the components in a correlated colour temperature (CCT) range of $2500-7000 \mathrm{~K}$. In addition, acceptable criterion of the colour fidelity index above 85 is used. It is shown that under this condition the circadian action factor in the range of $0.33-0.98$ can be obtained by changing the CCT and (or) colour fidelity index. Also an achievable area of the circadian stimulus versus corneal illuminance space for RGBW systems is found. It enables to choose optimal combination of CCT, circadian stimulus and corneal illuminance to provide the desired level of circadian effect with sufficient visual comfort depending on the daytime and field of system's implementation. This data is useful for LS manufacturers and lighting designers to create a comfortable lighting environment.
\end{abstract}

Keywords - RGBW colour mixing, tunable white light, circadian effect, colour rendering, colour fidelity index.

\section{INTRODUCTION}

The non-visual impact of light on human, its productivity, well-being and health is already proven [13]. Over the past few decades, a study of this influence, its nature and assessment methods have been actively conducted [4-8]. The rapid development of this field is associated with the discovery of photosensitive Retinal Ganglion Cells (ipRGCs) being signal transmitter to the suprachiasmatic nucleus that is responsible for the circadian rhythm of humans through the hormone melatonin secretion [9-12]. Nocturnal melatonin suppression is an endocrine disruptor and can lead to fatigue, diabetes, obesity and other diseases, even to cancer $[13,14]$. Therefore, it is important to continue studying the impact of light on human and take into account this impact when creating light environment.

Analysis of the ipRGCs and melatonin secretion sensitivities to different wavelengths showed that the human circadian system and visual system have different sensitivity functions. The first one has sensitivity peak in the blue spectral region and the second one - in the green region for photopic vision $(555 \mathrm{~nm})$. The first model of circadian spectral sensitivity was proposed by Gall et al. [15] and its maximum is in the range of $445-465 \mathrm{~nm}$. Later Rea et al. [16] proposed a more accurate model which is based on the retina's neurophysiology and neuroanatomy, and takes into account studies [10,17] of nocturnal melatonin suppression caused by light with different spectral power distributions (SPDs). According to the data, there are three main parameters for evaluating the circadian effect of light sources. They include (i) the circadian light $\mathrm{CL}_{\mathrm{A}}$ being an analogue of visual illuminance, related (ii) circadian stimulus CS [11,18] being the percentage of melatonin suppression for an hour exposure, as well as (iii) circadian action factor $\mathrm{a}_{\mathrm{CV}}$ representing the ratio of circadian and visual stimulus. All these parameters are affected predominantly by the SPD, while $\mathrm{CL}_{\mathrm{A}}$ and $\mathrm{CS}$ are also affected by the visual corneal illuminance and time. At the same time, important parameters of visual perception of light are colour rendering and correlated colour temperature (CCT) $[19,20]$. Today, more attention is paid to these visual parameters and luminous efficacy when developing and choosing lighting systems. But due to the difference in the visual and non-visual perception of light, developers and designers have to take into account both types of parameters to create comfortable lighting environment. And the main benchmark is the similarity of the parameters of artificial lighting to daylighting which is the most comfortable for human. The most promising systems in terms of tunability of the CCT and other parameters are 4-component systems, such as RGBW 
D. Kalustova, V. Kornaga, A. Rybalochka, S. Valyukh Issue 57, Vol. 01.

(red/green/blue/white) and RGBA (red/green/blue/amber) systems [21-23] since they offer much more combinations of visual and non-visual parameters than 2- or 3component systems [22,24].

In this paper, we explore two RGBW systems and the space of visual and circadian parameters that they can ensure to determine optimal combination of LEDs contributions according to the field of system's implementation. The capabilities of these systems to ensure circadian effect are studied using the Rea et al. model [16]. For determination of the colour rendering the IES colour fidelity index $\mathrm{Rf}$ and gamut index $\mathrm{Rg}$ [25] are used since they are more accurate than colour rendering index (CRI) and therefore are recommended by CIE for scientific use [19].

\section{RESEARCH CONDITIONS}

Two RGBW lighting systems are considered. They have the same red, green and blue LEDs (R,G,B), but different white LEDs: the first one - $\mathrm{RGBW}_{\mathrm{W}}$ system has warm white $\left(\mathrm{W}_{\mathrm{W}}\right)$ LED with $\mathrm{CCT}_{\mathrm{Ww}}=2985 \mathrm{~K}$ (CRI 82, Rf 83 ), and the second one - $\mathrm{RGBW}_{\mathrm{N}}$ system has neutral white $\left(\mathrm{W}_{\mathrm{N}}\right)$ LED with $\mathrm{CCT}_{\mathrm{WN}}=4026 \mathrm{~K}(\mathrm{CRI} 81$, Rf 81). The $\mathrm{W}_{\mathrm{W}}$ and $\mathrm{W}_{\mathrm{N}}$ LEDs were chosen for the study since the analysis of the influence of the white LED on the parameters of the resulting light of RGBW systems showed impractical use of the cool white LEDs [26]. The pick wavelengths of R, G and B LEDs are $625 \mathrm{~nm}, 525$ $\mathrm{nm}$ and $461 \mathrm{~nm}$ respectively. Two normalized spectral power distributions of the $\mathrm{W}_{\mathrm{W}}$ and $\mathrm{W}_{\mathrm{N}}$ LEDs used in the systems are shown by the dashed lines in Fig.1 together with photopic luminous efficiency function $V(\lambda)$ and two circadian spectral sensitivity functions $\mathrm{c}(\lambda)$ according to Gall et al. [15] and Rea et al. [16] models.

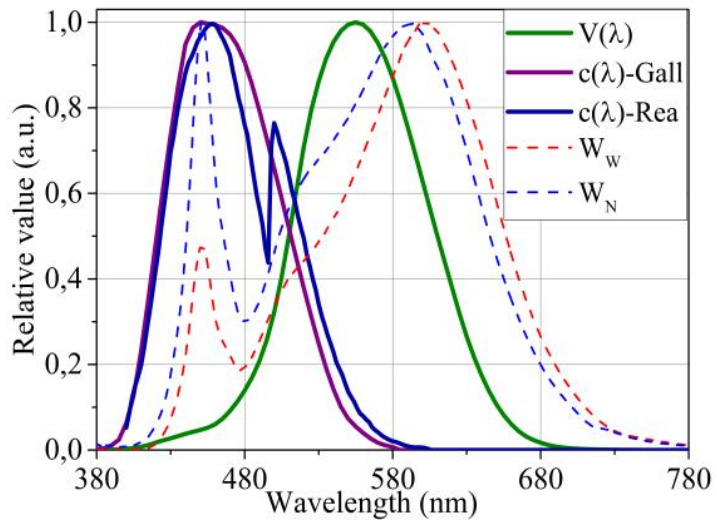

Fig. 1. The photopic luminous efficiency function $V(\lambda)$, the circadian spectral sensitivity $\mathrm{c}(\lambda)$ according to Gall [15] and Rea [16] models, and spectral power distributions of the warm white

$\left(\mathrm{W}_{\mathrm{W}}\right)$ and neutral white $\left(\mathrm{W}_{\mathrm{N}}\right)$ LEDs used in the clusters.

To explore the space of possible values of colour rendering and circadian parameters of the described systems, the SPDs of the resulting light are generated for different contribution of RGB-component. Due to the fact that illumination's similarity to natural lighting is associated with location of a colour (i.e. its chromaticity coordinates) on the Planckian locus on the CIE chromaticity diagram, in this work study is carried out along the Planckian locus within the CCT range $2500-$
$6000 \mathrm{~K}$ with $500 \mathrm{~K}$ step and at $7000 \mathrm{~K}$. Each CCT is obtained for eight different RGB-contributions being equidistant geometrically on the CIE chromaticity diagram. Examples of the chromaticity coordinates of the resulting light and schematic coordinates of the used LEDs are shown in Fig. 2. The RGB-contribution changes by changing the position of the RGB point (i.e. chromaticity coordinates of the resulting light of three coloured LEDs) along the ray with initial point $\mathrm{W}_{\mathrm{W}}$ (or $\mathrm{W}_{\mathrm{N}}$ ) passing through the resulting point on the Planckian locus. Since position of the points $\mathrm{W}_{\mathrm{W}}, \mathrm{W}_{\mathrm{N}}$ and resulting white light for each CCT are fixed, it is only the RGB-contribution that regulates the spectrum of the resulting light and, therefore, its colour rendering and circadian parameters. It should be noted that as the distance between the RGB point and Planckian locus increases, RGB-contribution to the resulting light decreases. Thus, SPDs and parameters of the resulting light are calculated for different RGBcontributions in a wide CCT range. It allows evaluating the capabilities of RGBW systems to provide an optimal combination of visual and non-visual parameters.

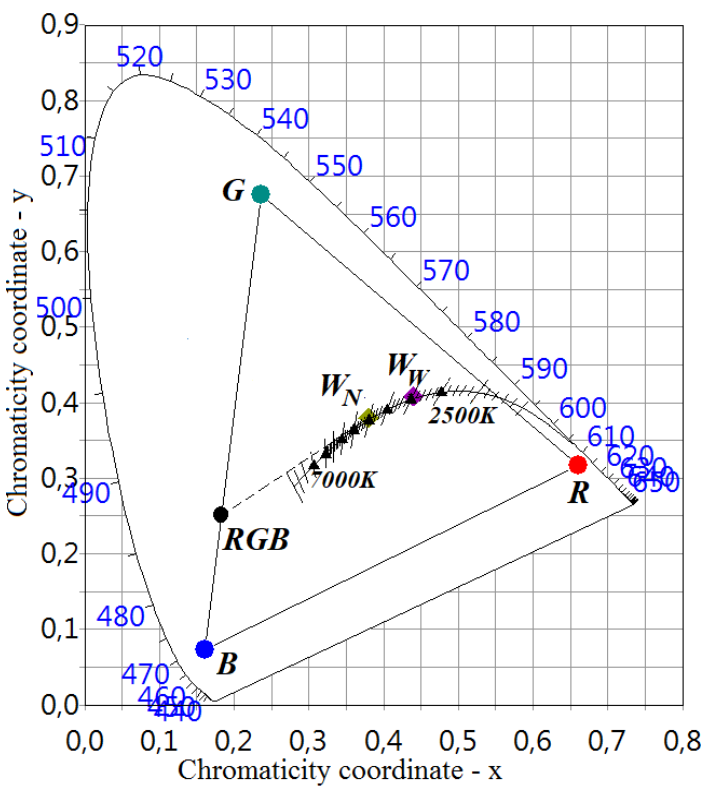

Fig. 2. CIE diagram with schematic chromaticity coordinates of red, green, blue, warm white and neutral white LEDs $\left(R, G, B, W_{W}\right.$,

$\mathrm{W}_{\mathrm{N}}$ ), and points of the resulting light on the Planckian locus.

\section{RESULTS AND DISCASSION}

Visual and non-visual parameters of the resulting RGBW light are calculated in the CCT range of $2500-$ $7000 \mathrm{~K}$. They include colour fidelity index Rf, gamut index $\mathrm{Rg}$, colour rendering index (CRI), the circadian light $\mathrm{CL}_{\mathrm{A}}$, circadian action factor $\mathrm{a}_{\mathrm{CV}}$ and circadian stimulus $\mathrm{CS}$ for different visual corneal illuminance. An analysis of the obtained colour rendering values shows that the CRI and Rf values have similar dependencies on the RGBcontribution and their maximum values are gotten at the same RGB-contribution. The CRI and Rf maximum values of two RGBW clusters at different CCTs are presented in Table 1. There are also the corresponding values of the gamut index, circadian action factor and circadian light at a corneal illuminance of $300 \mathrm{~lx}$ that herewith obtained. Thus, for the $\mathrm{RGBW}_{\mathrm{W}}$ and $\mathrm{RGBW}_{\mathrm{N}}$ systems the maximum 
CRI values varies in the ranges $82-97$ and $56-97$, while maximum $\mathrm{Rf}$ values are $86-93$ and $70-92$, respectively. But as already mentioned, maximizing colour rendering is not a criterion for the quality of light in terms of its nonvisual impact on human circadian rhythms.

To evaluate the effect of the RGBW clusters on the circadian system the circadian light $\mathrm{CL}_{\mathrm{A}}$ is calculated at different RGB-contribution. Its values at $3001 \mathrm{~lx}$ are chosen for the comparison since this corneal illuminance was proposed as the beginning of the "bright appearance" $[27,28]$. The $\mathrm{CL}_{\mathrm{A}}$ values at $300 \mathrm{~lx}$ as a function of CCT for RGBW $_{\mathrm{W}}$ and $\mathrm{RGBW}_{\mathrm{N}}$ systems and their comparison with a blackbody radiator are shown in Fig. 3. As is apparent, the relative effectiveness of the RGBW systems for stimulating the circadian system may vary for a given CCT at different LEDs contribution. As the RGBcontribution increases, the $\mathrm{CL}_{\mathrm{A}}$ value increases. And the RGB-contribution has a greater effect on circadian light at low CCT. Thus, the ranges of possible $\mathrm{CL}_{\mathrm{A}}$ values change within $1-6 \%$ at $4000-7000 \mathrm{~K}$ and $16-20 \%$ at $2500-$ $3000 \mathrm{~K}$ and more than twice at $3500 \mathrm{~K}$. This is due to the different types of response from the blue-yellow channel which is expressed by the parameter opp: opp $<0$ for the 'yellow' response being governed by the ipRGC and $o p p>0$ for the 'blue' response being governed by the ipRGC and S-cones. At the CCTs higher than $4000 \mathrm{~K}$ it is always positive.

TABLE I $\quad$ MAXIMUM VALUES OF COLOUR RENDERING INDEX $\left(\mathrm{CRI}_{\mathrm{MAX}}\right)$ AND FIDELITY INDEX $\left(\mathrm{RF}_{\mathrm{MAX}}\right)$, AND CORRESPONDING GAMUT INDEX (RG), CIRCADIAN ACTION FACTOR ( $\left.\mathrm{A}_{\mathrm{CV}}\right)$ AND CIRCADIAN LIGHT AT A CORNEAL ILLUMINANCE OF $300 \mathrm{LX}\left(\mathrm{C}_{\mathrm{LA}}\right)$ IN THE CCT RANGE OF $2500 \mathrm{~K}$ $-7000 \mathrm{~K}$ FOR TWO CLUSTERS.

\begin{tabular}{|l|c|c|c|c|c|c|c|c|c|c|}
\hline \multirow{2}{*}{ CCT,K } & \multicolumn{5}{|c|}{ RGBW $_{\mathbf{W}}$} & \multicolumn{5}{|c|}{ RGBW $_{\mathbf{N}}$} \\
\cline { 2 - 13 } & $\boldsymbol{C R I}_{\max }$ & $\boldsymbol{R} \boldsymbol{f}_{\max }$ & $\boldsymbol{R} \boldsymbol{g}$ & $\boldsymbol{a}_{\boldsymbol{C} V}$ & $\boldsymbol{C L}_{\boldsymbol{A}}$ & $\boldsymbol{C R I}_{\max }$ & $\boldsymbol{R} \boldsymbol{f}_{\max }$ & $\boldsymbol{R g}$ & $\boldsymbol{a}_{\boldsymbol{C V}}$ & $\boldsymbol{C L}_{\boldsymbol{A}}$ \\
\hline $2500 \mathrm{~K}$ & 82 & 86 & 108 & 0.33 & 257 & 56 & 70 & 114 & 0.36 & 281 \\
\hline $3000 \mathrm{~K}$ & 97 & 93 & 102 & 0.41 & 305 & 77 & 85 & 110 & 0.44 & 321 \\
\hline $3500 \mathrm{~K}$ & 97 & 92 & 101 & 0.51 & 368 & 96 & 92 & 103 & 0.50 & 136 \\
\hline $4000 \mathrm{~K}$ & 97 & 90 & 99 & 0.56 & 206 & 89 & 86 & 98 & 0.58 & 196 \\
\hline $4500 \mathrm{~K}$ & 96 & 89 & 100 & 0.68 & 266 & 97 & 90 & 101 & 0.69 & 259 \\
\hline $5000 \mathrm{~K}$ & 96 & 89 & 99 & 0.75 & 319 & 97 & 90 & 101 & 0.74 & 313 \\
\hline $5500 \mathrm{~K}$ & 95 & 89 & 100 & 0.81 & 368 & 97 & 90 & 101 & 0.80 & 361 \\
\hline $6000 \mathrm{~K}$ & 95 & 88 & 99 & 0.87 & 413 & 96 & 89 & 99 & 0.86 & 405 \\
\hline $7000 \mathrm{~K}$ & 94 & 86 & 98 & 0.97 & 487 & 95 & 88 & 99 & 0.96 & 482 \\
\hline
\end{tabular}

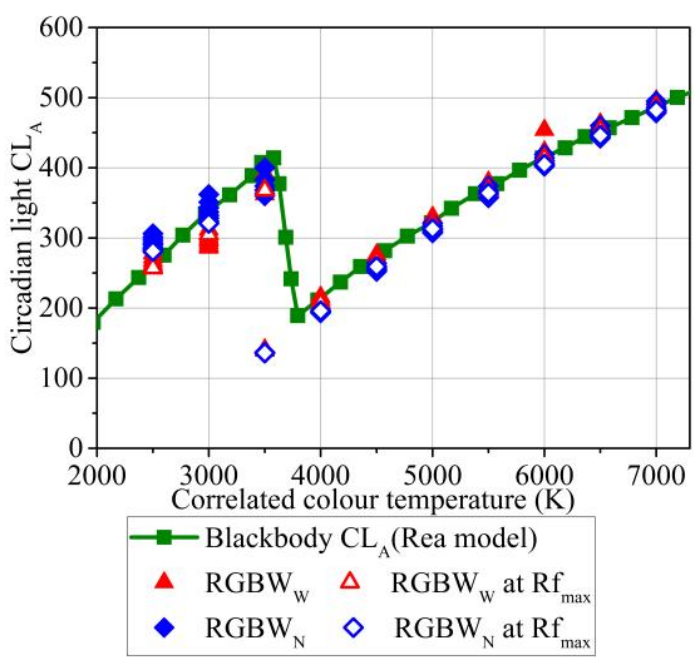

Fig. 3. The relative effectiveness of 300 lux corneal illuminance for a blackbody radiator for circadian system stimulation according to the Rea model [16], for RGBW $\mathrm{W}_{\mathrm{W}}$ and $\mathrm{RGBW}_{\mathrm{N}}$ systems with different LEDs contributions at CCTs from $2500 \mathrm{~K}$ to $7000 \mathrm{~K}$, and for these systems while the Rf values are maximal.

The limitation of light sources with fixed CCT (i.e. fixed SPD) is that their colour rendering and circadian action factor are also fixed due to their determination only by SPD. For a such white light sources of different origin (incandescent, fluorescent, LED lamps) with similar CCT values it was already shown the absence of the circadian dependence of the "dose of blue light" and almost a linear increase of it with the CCT increase [29]. This "dose" was proportional to the $\mathrm{a}_{\mathrm{CV}}$ parameter and calculated using Gall model [15].

Conversely, in the RGBW systems it is possible to change SPD smoothly changing colour rendering and $\mathrm{a}_{\mathrm{CV}}$ parameters. To explore in detail, the space of visual and circadian parameters that can ensure two considered clusters, it is obtained a series of achievable colour rendering and circadian action factors for each target CCT. The simulation results for fidelity index $\mathrm{Rf}$ versus $\mathrm{a}_{\mathrm{CV}}$ (calculated using Rea model) in the CCT range 2500 $7000 \mathrm{~K}$ are presented in Fig. 4. The circadian action factors of the $\mathrm{W}_{\mathrm{W}}$ and $\mathrm{W}_{\mathrm{N}}$ LEDs without adding RGB-component are 0.38 and 0.56 respectively.

As expected, the calculated $\mathrm{a}_{\mathrm{CV}}$ values increase with the increase of the CCT. Thus, its minimum value $(0.33)$ is achieved at $2500 \mathrm{~K}$ and maximum value $(0.99)$ - at $7000 \mathrm{~K}$. According to Fig. 3, at some CCTs the circadian action factor has two boundary values that differ up to $5 \%$ while fidelity index Rf is the same. This increase opportunity of such systems, allowing to regulate the circadian effect without changing the colour rendering. A calculation of colour rendering index CRI for two considered RGBW systems showed similar dependence on $\mathrm{a}_{\mathrm{CV}}$ but different numerical values (predominantly higher). 

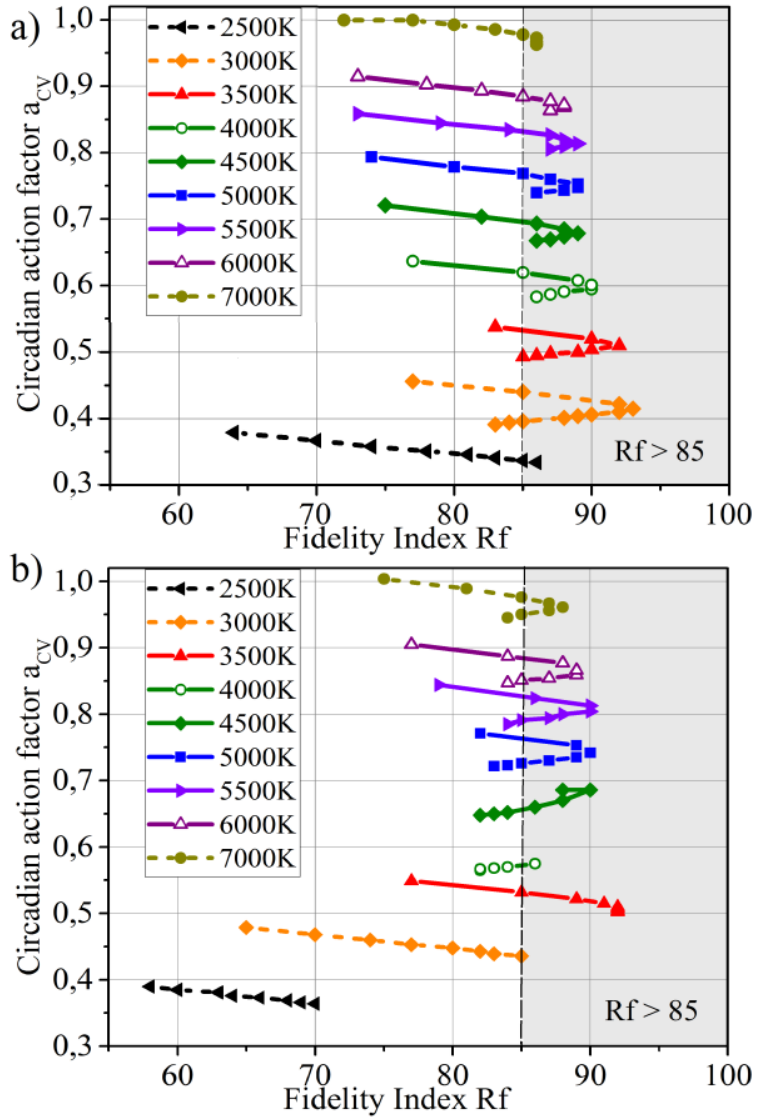

Fig. 4. IES fidelity index Rf versus circadian action factor $\left(\mathrm{a}_{\mathrm{CV}}\right)$ for the CCTs from 2500 to $7000 \mathrm{~K}$ for RGBW systems with basic Warm (a) and Neutral (b) White LEDs.

The gray area in Fig. 4 indicates an acceptable criterion that the fidelity index $\mathrm{Rf}$ is above 85 . Under this condition, the $\mathrm{a}_{\mathrm{CV}}$ can reach values from 0.33 at $2500 \mathrm{~K}$ to 0.98 at $7000 \mathrm{~K}$ in the $\mathrm{RGBW}_{\mathrm{W}}$ system and from 0.44 at $3000 \mathrm{~K}$ to 0.98 at $7000 \mathrm{~K}$ in the $\mathrm{RGBW}_{\mathrm{N}}$ system. Any circadian action factor between these boundary values can be obtained by changing the CCT and (or) colour rendering.

Each SPD also allows to evaluate the corresponding percentage of melatonin suppression as a function of visual corneal illuminance $\left(\mathrm{E}_{\mathrm{v} \text { cor }}\right)$. This circadian stimulus CS is calculated for an hour exposure on the presumption that pupil has fixed diameter $2.3 \mathrm{~mm}[11,18]$. It is ranges from 0 to $70 \%$, where $5 \%$ is a working threshold, $35 \%$ and $70 \%$ are levels of half saturation and saturation of circadian activation, respectively [5]. Since in the RGBW system each CCT can be obtained by many different SPDs, it is possible to calculate achievable combinations of the CS and $\mathrm{E}_{\mathrm{v} \text { cor }}$ for each CCT. Thus, one can choose an optimal combination of circadian stimulus and $\mathrm{E}_{\mathrm{v} \text { cor for }}$ desired CCT by optimising SPD (i.e. regulating LEDs contributions) and the light output.

A complete calculation of circadian stimulus for a wide CCT range allows to find out achievable area of the $\mathrm{CS}$-versus- $\mathrm{E}_{\mathrm{v} \text { cor }}$ space for considered system and thus, choose preferred combination of CCT, CS and $\mathrm{E}_{\mathrm{v} \text { cor }}$ according to the lighting-design scenarios. Fig. 5 shows achievable area of the CS-versus- $\mathrm{E}_{\mathrm{v}}$ cor space for $\mathrm{RGBW}_{\mathrm{W}}$ system in compliance with the specified earlier condition that the fidelity index $\mathrm{Rf}$ is above 85 . It is limited by $3500 \mathrm{~K}$ and $7000 \mathrm{~K}$ because the corresponding area for $2500-3000 \mathrm{~K}$ are within the range indicated in Fig. 5. That is because of change in the type of response from the blue-yellow channel at $3500 \mathrm{~K}$ and negative parameter opp (the 'yellow' response) for the low CCTs. Thus, the circadian effect increases with increase of CCT from $3500 \mathrm{~K}$ to $7000 \mathrm{~K}$, but for $2500 \mathrm{~K}$ and $3000 \mathrm{~K}$ it is close to corresponding values for $4500 \mathrm{~K}$ and $5000 \mathrm{~K}$, respectively. To induce 5\% nocturnal melatonin suppression, it is needed one-hour light exposure of about $22 \mathrm{~lx}$ at $7000 \mathrm{~K}$ or about $75 \mathrm{~lx}$ at $3500 \mathrm{~K}$. Similarly, to induce $35 \%$ of melatonin suppression it is needed one-hour light exposure of about $250 \mathrm{~lx}$ at $7000 \mathrm{~K}$ or $700 \mathrm{~lx}$ at $3500 \mathrm{~K}$. So, if there is no significant difference in CCT choice for some applications, one can find the maximum possible level of corneal illuminance at the desired CS for comfortable lighting.

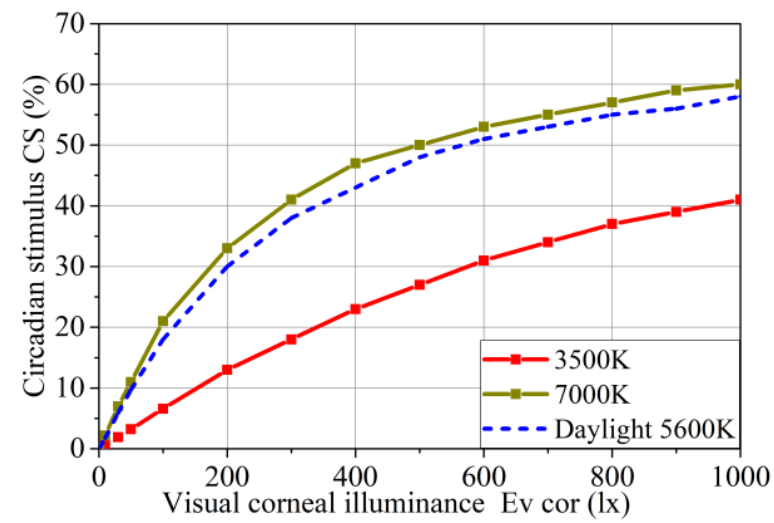

Fig. 5. Achievable area of circadian stimulus (CS) versus visual corneal illuminance $\left(\mathrm{E}_{\mathrm{v} \text { cor }}\right)$ for $\mathrm{RGBW}_{\mathrm{W}}$ system at $\mathrm{Rf}$ above 85 , and for measured daylight spectrum at $5600 \mathrm{~K}$.

Fig. 5 also contains for comparison a dependence for the spectrum of daylight at $5600 \mathrm{~K}$ being measured at the solstice at cloudless weather conditions at the roof of the V. Lashkaryov Institute of Semiconductor Physic NASU (Kyiv, Ukraine $\left(50^{\circ} 23^{\prime} 27.3^{\prime \prime N}, 30^{\circ} 31^{\prime} 48.6^{\prime \prime} \mathrm{E}\right)$ ). Since this dependence is within the achievable area it is possible to reproduce these values of circadian stimulus and corneal illuminance of daylighting by using RGBW system.

\section{CONCLUSIONS}

In this work, we demonstrate the space of visual and non-visual parameters that can be achieved by RGBW systems. It is shown the range of possible values of circadian stimulus and circadian action factor that can be obtained while the fidelity index $\mathrm{Rf}$ is above 85 . While often the choice of light sources is based on maximizing colour rendering and CCT tunability, this study of achievable area of the visual and circadian parameters enables to choose optimal combination of CCT, circadian stimulus and corneal illuminance for comfortable environment according to the lighting-design scenarios. For example, it is possible to change dynamically these parameters during a day to provide sufficient CS values during daytime, and low CS values (below 5\%) in the evening so as not to disturb the natural circadian rhythms of human. 
This study provides useful data for manufacturers of LED systems and lighting designers to create a comfortable lighting environment for work and leisure.

\section{REFERENCES}

[1] A. J. Lewy, T. A. Wehr, F. K. Goodwin, D. A. Newsome, and S. P. Markey, "Light suppresses melatonin secretion in humans," Sci., vol. 210, pp. 1267-1269, Dec. 1980.

[2] L. Bellia, F. Bisegna, and G. Spada, "Lighting in indoor environments: visual and non-visual effects of light sources with different spectral power distributions," Build. Environ., vol. 46, pp.1984-1992, Oct. 2011.

[3] G.C. Brainard, and J.P. Hanifin, "The Effects of light on human health and behavior: relevance to architectural lighting," x027:2004 CIE Symp. Light Health: non-visual effects, Austria.

[4] K. Konis, "A novel circadian daylight metric for building design and evaluation," Build. Environ., vol. 113, pp. 22-38, Feb. 2017.

[5] I. Acosta, R. P. Leslie, and M. G. Figueiro, "Analysis of circadian stimulus allowed by daylighting in hospital rooms," Light. Res. Technol., vol. 49, pp. 49-61, Jun. 2015.

[6] D. Gall and K. Beiske, "Definition and measurement of circadian radiometric quantities," Proc. CIE Symp. Light Health: Non-visual Effects, 2004, pp. 129-132.

[7] L.A. Nazarenko, K.I. Ioffe, E.P. Timofeev, "The estimation of biological action of light", Light. Eng. Power Eng., vol. 3-4, pp. 410, 2007.

[8] L.A. Nazarenko, K.I. Ioffe, "Circadian efficient for LED lighting", Light. Eng. Power Eng., vol. 3-4, pp. 33-41, 2013.

[9] D.M. Berson, F.A. Dunn, and T. Motoharu, "Phototransduction by retinal ganglion cells that set the circadian clock," Sci., vol. 295, pp 1070-1073, Feb. 2002.

[10] G.C. Brainard, J.P. Hanifin, J.M. Greeson, B. Byrne, G. Glickman, E. Gerner et al., "Action spectrum for melatonin regulation in humans: evidence for a novel circadian photoreceptor," $J$. Neurosci., vol. 21, pp. 6405-6412, Aug. 2001.

[11] M.S. Rea, M.G. Figueiro, A. Bierman, and J.D. Bullough, "Circadian Light," J. Circadian Rhythms, vol. 8, pp. 1-10, Feb. 2010.

[12] G.C. Brainard, D. Sliney, J.P. Hanifin, G. Glickman, B. Byrne et al., "Sensitivity of the human circadian system to short-wavelength (420-nm) light," J. Biol. Rhythms, vol. 23, pp. 379-386, Oct. 2008.

[13] R.J. Reiter, D.X. Tan, A. Korkmaz, and S. Ma, "Obesity and metabolic syndrome: association with chronodisruption, sleep deprivation, and melatonin suppression," Ann. Med., vol. 44(6), pp. 564-577, Sep. 2012.

[14] S. Davis, D.K. Mirick, R.G. Stevens, "Night shift work, light at night, and risk of breast cancer," J. Natl. Cancer Inst., vol. 93, pp. 1557-1562, Oct. 2001.
[15] D. Gall, "Circadiane Lichtgrößen und deren messtechnische Ermittlung," Licht, vol. 54, pp. 1292-1297, 2002.

[16] M.S. Rea, M.G. Figueiro, A. Bierman, and R. Hamner, "Modelling the spectral sensitivity of the human circadian system," Light. Res. Technol., vol. 44, pp. 386-396, Dec. 2012.

[17] K. Thapan, J. Arendt, D.J. Skene, "An action spectrum for melatonin suppression: evidence for a novel non-rod, non-cone photoreceptor system in humans," J. Physiol., vol. 535, pp. 261267, Aug. 2001.

[18] M.S. Rea and M.G. Figueiro, "A Working Threshold for Acute Nocturnal Melatonin Suppression from "White" Light Sources used in Architectural Applications," J. Carcinogene Mutagene, vol. 4(3), pp. 1-6, Jan. 2013.

[19] CIE 224:2017: Colour fidelity index for accurate scientific use, CIE Publication, Vienna, 2017.

[20] C. Li, G. Cui, M. Melgosa, X. Ruan, Y. Zhang, et al., "Accurate method for computing correlated colour temperature," Opt. Express, vol. 24(13), pp. 14066-14078, Jun. 2016.

[21] V.I. Kornaga, V.M. Sorokin, A.V. Rybalochka, O.S. Oliinyk, and N.P. Kornaga, "Colour mixing models for smart lighting systems based on RGBW and WW LEDs", Semicond. Phys. Quantum Electron. Optoelectron., vol. 18(3), pp. 302-308, Sep. 2015.

[22] G. He and L. Zheng, "Colour temperature tunable white-light lightemitting diode clusters with high colour rendering index," Appl. Opt., vol. 49(24), pp. 4670-4676, Aug. 2010.

[23] D. Kalustova, V. Kornaga, A. Rybalochka, Y.-J. Yu, S. Valyukh, "Color temperature tunable RGBW clusters with 3 control channels," Photonics Lett. Poland, vol. 12(1), pp. 10-12, Mar. 2020.

[24] D. Lin, P. Zhong, and G. He, "Colour temperature tunable white LED cluster with colour rendering index above 98," IEEE Photon. Technol. Lett., vol. 29, pp. 1050-1053, May 2017.

[25] Illuminating Engineering Society of North America, IES method for evaluating light source colour rendition, IES TM-30-18, 2018.

[26] V. Kornaga, D. Kalustova and O. Oliynyk, "Modeling the spectral characteristics of lighting systems to obtain high CRI of the resulting light in the range of color temperatures of $3000 \mathrm{~K}-$ $7000 \mathrm{~K}$ ", in 6th Int. Sci. Conf. "Light. Power. Eng.: hist, probl, perspect", Ternopil, Ukraine, 2018, pp. 43-44.

[27] C. Cuttle, "Towards the third stage of the lighting profession," Light. Res. Technol., vol. 42, pp. 73-93, Mar. 2010.

[28] C. Cuttle, Lighting Design: a perception-based approach. New York, NY, Routledge, 2015.

[29] D.O. Kalustova, A.I. Baieva, O.I. Rudenko, O.V. Makarenko, and A.V. Rybalochka, "Evaluation of the white LED lighting on human circadian rhythms," Bull. Taras Shevchenko National University of Kyiv, Ser. Phys. Math., vol. 4, pp. 98-101, 2016.

\section{Простір візуальних і циркадних параметрів RGBW-систем освітлення}

Д.О. Калустова,

Інститут фізики напівпровідників ім.

В.С. Лашкарьова НАН України, Україна

А.В. Рибалочка

Інститут фізики напівпровідників ім. В.С. Лашкарьова НАН України, Україна,
Україна В.I. Корнага, Інститут фізики напівпровідників ім. В.Є. Лашкарьова НАН України, Україна

\section{С.I. Валюх}

Кафедра фізики, хімії та біології Лінчепінзький університет Швеція 
D. Kalustova, V. Kornaga, A. Rybalochka, S. Valyukh Вип.51, №01.

Анотація - Завдяки доведеному впливу світла на циркадні ритми людини, дослідники та розробники освітлювальних систем все більше уваги приділяють невізуальним параметрах світла та методах забезпечення безпечного комфортного освітлення. Це вимагас оптимізації спектрального складу випромінювання. Найбільш перспективними і функціональними, з цієї точки зору, с 4-компонентні системи освітлення RGBW (червоний-зеленийсиній-білий) завдяки їх здатності динамічно змінювати спектральну характеристику і, відповідно, параметри результуючого світла. У цій роботі ми досліджусмо дві системи RGBW та простір візуальних та невізуальних параметрів, які вони можуть забезпечити. Серед візуальних параметрів визначаються кольоропередача та освітленість рогівки, а серед невізуальних параметрів - циркадне світло $\left(\mathrm{CL}_{\mathrm{A}}\right)$, циркадний стимул $(\mathrm{CS})$ та коефіціснт циркадної ефективності (acv). Ці параметри розраховуються при різному внеску світлодіодів у результуюче світло у діапазоні корельованих колірних температур (ССТ) від 2500 К до 7000 К. Додатково використовується прийнятний критерій, згідно якого індекс точності відтворення кольорів Rf вищий за 85. Показано, що за цієї умови можна отримати коефіцієнт циркадної ефективності в діапазоні 0,33-0,98 шляхом зміни СCT та (або) Rf. Також визначено досяжну зону простору циркадного стимулу та освітленості рогівки для систем RGBW. Це дозволяє обрати оптимальну комбінацію ССТ, циркадного стимулу та освітленості рогівки для забезпечення бажаного рівня циркадного ефекту при комфортному візуальному сприйнятті залежно від часу доби та сфери застосування системи. Ці дані корисні для виробників освітлювальних систем та дизайнерів освітлення.

Ключові слова - змішування кольорів RGBW, регульоване біле світло, циркадний ефект, кольоропередача, точність відтворення кольорів. 